\title{
Chromosome studies in Turnera (Turneraceae)
}

\author{
V.G. Solís Neffa ${ }^{1}$ and A. Fernández ${ }^{2}$
}

${ }^{I}$ Facultad de Ciencias Agrarias (UNNE).

${ }^{2}$ Facultad de Ciencias Exactas y Naturales y Agrimensura (UNNE). Miembro de la Carrera del Investigador Cientifico (CONICET). ${ }_{1,2}^{1,2}$ Instituto de Botánica del Nordeste (UNNE-CONICET), Casilla de Correo 209, (3400) Corrientes, Argentina. Send correspondence to V.G.S.N.

The genus Turnera is one of the most important genera of the Turneraceae comprising more than 100 species grouped in 9 series (Urban, 1883) which are distributed largely in tropical and subtropical areas of the Americas.

At least $34 \%$ of all species have been karyologically investigated. Chromosome numbers have been reported for 35 species (Raman and Kesavan, 1964; Hamel, 1965; Barrett, 1978; Barrett and Shore, 1980; Arbo and Fernández, 1983; Fernández, 1987; Solís Neffa and Fernández, 1993) but the karyotypes of only 21 have been described (Solís Neffa and Fernández, 1993; Solís Neffa, 1996).

The basic chromosome number $\mathrm{x}=7$ was found in the Salicifolieae, Stenodictyae, Mycrophyllae and Leiocarpae series and is clearly the most common, $\mathrm{x}=5$ was found in the Turnera (=Canaligerae) series and $\mathrm{x}=13$ in the Papilliferae (Fernández, 1987).

Cytological investigation has shown the occurrence of diploid to decaploid populations, that may be autopolyploids as well as allopolyploids (Raman and Kesavan, 1964; Barrett, 1978; Arbo and Fernández, 1983; Shore and Barrett, 1985; Fernández, 1987). From these studies it is apparent that polyploidy has played an important and sometimes dominant role in speciation within the genus. However, chromosome rearrangements may be involved in the karyotype evolution of some species (Solís Neffa and Fernández, 1993; Solís Neffa, 1996).

Chromosome studies have been particularly detailed in the Turnera series, focusing on taxonomy and phylogenetic relationships. Since 1982 a controlled crossing program within this series has been carried out and several interespecific hybrids obtained and, as a result of cytogenetic studies, the genomic relationships of some species have been analyzed (Fernández and Arbo, 1989, 1990, 1993a,b, 1996; Fernández, 1997).

In this article we provide a review on the karyology of the whole genus for a better understanding of the chromosomal evolution of Turnera.

\section{POLYPLOIDY}

Polyploidization has long been recognized as an important process in plant evolution. In the genus Turnera, $59 \%$ of the population analyzed have polyploid origin, ranging from tetraploids to decaploids (Table I), with tetraploids and hexaploids more or less common and octoploids and decaploids rare (Table II).

Published counts together with our unpublished data reveal intraspecific polyploidy in several widespread species, some of which contain populations with $2 \mathrm{x}$ or $4 \mathrm{x}$ cytotypes, while $T$. grandiflora possesses $2 \mathrm{x}$ and $8 \mathrm{x}$ cytotypes. $T$. sidoides $(\mathrm{x}=7)$ includes 5 subspecies that are known to be comprised of different ploidy levels, from $2 x$ to $8 x$ (Fernández, 1987), which makes it possible to conclude that $T$. sidoides is a polyploid complex.

Autopolyploidy is apparently less frequent than allopolyploidy, but some workers suggest that the occurrence of autopolyploidy may have been underestimated (Soltis and Riesberg, 1986): of the polyploid species of Turnera about $35 \%$ are autopolyploids.

Autopolyploids are usually considered to be recognizable by multivalent chromosome configuration during meiosis metaphase, while the chromosomes of allopolyploids are assumed to pair into bivalents during meiosis. Most natural polyploids, however, fall somewhere in between these two extremes in genome constitution, combining more or less well-differentiated genomes of closely related species. The terms auto-, allo- and segmental allopolyploids refer to the combination of fully homologous, non-homologous and partly homologous chromosome sets (Greilhuber and Ehrendorfer, 1988).

Data on meiotic behavior obtained from the T. sidoides complex $(\mathrm{x}=7)$ showed high levels of multivalent formation with quadrivalents, hexavalents and octavalents, in $4 \mathrm{x}$, $6 \mathrm{x}$ and $8 \mathrm{x}$ cytotypes, respectively, characterizing them as autopolyploids (Fernández, 1987). Among tetraploid species of Turnera series $(\mathrm{x}=5)$, tetravalents were found in all cells of T. subulata, T. scabra (Figure 1) and T. krapovickasii, chromosome-pairing analysis showing an autotetraploid origin. T. grandiflora possesses $2 \mathrm{x}$ and $8 \mathrm{x}$ cytotypes, with the diploid showing regular pairing while the other cytotype behaved like an auto-octoploid since it showed octavalent formation (Figure 1).

A detailed meiotic study of $T$. grandidentata, $2 \mathrm{n}=$ $4 \mathrm{x}=20$, T. ulmifolia, $2 \mathrm{n}=6 \mathrm{x}=30$, and T. orientalis, $2 \mathrm{n}=$ $6 \mathrm{x}=30$ (Figure 1), showed only bivalents (Fernández, 1987). Meiosis pairing was generally regular in $T$. aurelii $(2 \mathrm{n}=8 \mathrm{x}=40)$, but 18 II and 1 IV were also found. Cytological studies of hybrids between diploids and polyploids 
Table I - Species studied.

\begin{tabular}{|c|c|c|}
\hline Species & $2 \mathrm{n}$ & References \\
\hline \multicolumn{3}{|l|}{ Salicifoliae series } \\
\hline \multicolumn{3}{|l|}{ Turnera weddelliana } \\
\hline Urban \& Rolfe & 14 & Fernández, 1987 \\
\hline \multicolumn{3}{|l|}{ Stenodictyae series } \\
\hline T. macrophylla Urban & 14 & Fernández, 1987 \\
\hline \multicolumn{3}{|l|}{ Leiocarpae series } \\
\hline T. nervosa Urban & 14 & Fernández, 1987 \\
\hline T. pumilea $\mathrm{L}$. & 14 & Fernández, 1987 \\
\hline T. melochiodes Cambess. & 14 & Fernández, 1987 \\
\hline T. trigona Urban & 14 & $\begin{array}{l}\text { Solís Neffa and } \\
\text { Fernández, } 1993\end{array}$ \\
\hline \multirow{2}{*}{ T. hassleriana Urban } & 14 & Fernández, 1987 \\
\hline & 28 & Fernández, 1987 \\
\hline T. lamiifolia Cambess. & 28 & Fernández, 1987 \\
\hline \multirow[t]{2}{*}{ T. sidoides L. ssp. sidoides } & 28 & Fernández, 1987 \\
\hline & $32,34,39$ & Fernández, 1987 \\
\hline \multirow{3}{*}{$\begin{array}{l}\text { T. sidoides L. ssp. carnea } \\
\text { (Cambess.) Arbo }\end{array}$} & 14 & Fernández, 1987 \\
\hline & 28 & Fernández, 1987 \\
\hline & 42 & Fernández, 1987 \\
\hline \multirow{4}{*}{$\begin{array}{l}\text { T. sidoides L. ssp. integrifolia } \\
\text { (Griseb.) Arbo }\end{array}$} & 14 & Fernández, 1987 \\
\hline & 28 & Fernández, 1987 \\
\hline & 42 & Fernández, 1987 \\
\hline & 56 & Fernández, 1987 \\
\hline \multirow{2}{*}{$\begin{array}{l}\text { T. sidoides L. ssp. holosericea } \\
\text { (Urban) Arbo }\end{array}$} & 28 & Fernández, 1987 \\
\hline & 42 & Fernández, 1987 \\
\hline \multirow{3}{*}{$\begin{array}{l}\text { T. sidoides L. ssp. pinnatifida } \\
\text { (Juss. ex Poir.) Arbo }\end{array}$} & 14 & This paper \\
\hline & 28 & Fernández, 1987 \\
\hline & 42 & This paper \\
\hline T. opifera Mart. & 70 & Fernández, 1987 \\
\hline \multicolumn{3}{|l|}{ Microphyllae series } \\
\hline T. diffusa Willd. & 14 & Fernández, 1987 \\
\hline Papilliferae series & & Fernández, 1987 \\
\hline T. chamaedryfolia Cambess. & 26 & Fernández, 1987 \\
\hline \multicolumn{3}{|l|}{ Turnera $(=$ Canaligerae $)$ series } \\
\hline T. candida Arbo & 10 & $\begin{array}{l}\text { Solís Neffa and } \\
\text { Fernández, } 1993\end{array}$ \\
\hline T. caerulea DC. & 10 & Fernández, 1987 \\
\hline \multirow[t]{2}{*}{ T. grandiflora (Urban) Arbo } & 10 & Fernández, 1987 \\
\hline & 40 & Fernández, 1987 \\
\hline T. surinamensis Urban & 10 & Fernández, 1987 \\
\hline \multirow[t]{2}{*}{ T. subulata Smith } & 10 & Fernández, 1987 \\
\hline & 20 & Fernández, 1987 \\
\hline \multirow[t]{2}{*}{ T. scabra Millspaugh } & 10 & Fernández, 1987 \\
\hline & 20 & Fernández, 1987 \\
\hline \multirow[t]{2}{*}{ T. krapovickasii Arbo } & 10 & Fernández, 1987 \\
\hline & 20 & Fernández, 1987 \\
\hline T. concinna Arbo & 10 & Fernández, 1987 \\
\hline T. hermannioides Cambess. & 10 & Fernández, 1987 \\
\hline T. joelii Arbo & 10 & Fernández, 1987 \\
\hline T. grandidentata (Urban) Arbo & 20 & Fernández, 1987 \\
\hline T. arcuata Urban & 20 & $\begin{array}{l}\text { Solís Neffa and } \\
\text { Fernández, } 1993\end{array}$ \\
\hline T. angustifolia Miller & 30 & Fernández, 1987 \\
\hline T. orientalis (Urban) Arbo & 30 & Fernández, 1987 \\
\hline T. ulmifolia L. sensu stricto & 30 & Fernández, 1987 \\
\hline T. ulmifolia var. acuta & 30 & $\begin{array}{l}\text { Solís Neffa and } \\
\text { Fernández, } 1993\end{array}$ \\
\hline T. velutina Presl. & 30 & $\begin{array}{l}\text { Solís Neffa and } \\
\text { Fernández, } 1993\end{array}$ \\
\hline T. aurelii Arbo & 40 & Fernández, 1987 \\
\hline T. cuneiformis Poiret & 40 & $\begin{array}{l}\text { Solís Neffa and } \\
\text { Fernández, } 1993\end{array}$ \\
\hline
\end{tabular}

showed partly homologous chromosomes, suggesting that polyploid species are segmental allopolyploids (Fernández and Arbo, 1990, 1993a,b).

Pollen fertility of tetraploid species of Turnera ranged between $59 \%$ in T. hassleriana $(2 \mathrm{n}=28)$ and $94 \%$ in T. sidoides $\mathrm{ssp}$. holosericea $(2 \mathrm{n}=28)$. Among the autohexaploids pollen fertility varied from $67 \%$ in T. sidoides ssp. integrifolia $(2 \mathrm{n}=42)$ to $87 \%$ in $T$. sidoides $\mathrm{ssp}$. holosericea $(2 \mathrm{n}=6 \mathrm{x}=42)$. Pollen stainability of autooctoploids ranged from $71 \%$ in $T$. grandiflora $(2 \mathrm{n}=8 \mathrm{x}=$ $40)$ to $75 \%$ in $T$. sidoides ssp. integrifolia $(2 n=8 x=56)$. Low fertility, primarily caused by multivalent formation, is known to constrain autopolyploid evolution, and selection for increased fertility may lead to cytological diploidization in polyploids (De Wet, 1980), so that the high pollen fertility in autopolyploids would correlate with the degree of diploidization observed in meiosis (Fernández, 1987).

In many autopolyploids, the cytotypes contrast in geographical distribution, an example being T. sidoides, which is mostly native to the Chaco Phytogeographical Domain and is spread throughout the southern regions of Bolivia and Brazil, Paraguay and Uruguay until it reaches $39^{\circ} \mathrm{S}$ in Argentina and is the Turnera species with the most southerly distribution in the Americas (Arbo, 1986). In a preliminary analysis of the geographical distribution of the cytotypes of $T$. sidoides, greater variability was found in areas where the subspecies cohabit (Fernández, A. and Arbo, M.M., unpublished results).

Species of the Turnera series are mostly distributed in northern Brazil, where the 2x cytotype prevails, but in Central America and the Antilles the cytotypes are mainly 4x and 6x (Barrett, 1978; Shore and Barrett, 1985) while Paraguay has the highest levels of allopolyploids and autopolyploids and constitutes an important certer of speciation (Arbo, 1986).

\section{KARYOTYPE DATA AND SYSTEMATICS}

Karyological information is available for 6 of 9 recognized series in the genus and so far has concentrated on species of Turnera series. Detailed analysis of numerical data suggests that the karyotypes of the species of the genus, although very similar, can be distinguished into differ-

Table II - Incidence of polyploidy in 111 populations of Turnera (counts made at IBONE).

\begin{tabular}{|lccccc|}
\hline Series & $2 \mathrm{x}$ & $4 \mathrm{x}$ & $6 \mathrm{x}$ & $8 \mathrm{x}$ & $10 \mathrm{x}$ \\
\hline Salicifoliae & 1 & - & - & - & - \\
Stenodictyae & 1 & - & - & - & - \\
Leiocarpae & 14 & 28 & 8 & 1 & 1 \\
Microphylae & 1 & - & - & - & - \\
Papilliferae & 2 & - & - & - & - \\
Turnera & 27 & 13 & 10 & 4 & - \\
Total & 46 & 41 & 18 & 5 & 1 \\
$\%$ & $41.44 \%$ & $36.94 \%$ & $16.22 \%$ & $4.5 \%$ & $0.9 \%$ \\
\hline
\end{tabular}


ent groups, mainly in terms of mean chromosome length, type and position of satellites and karyotype asymmetry (Solís Neffa and Fernández, 1993).

Chromosomes of Turnera are small $(2.25 \mu \mathrm{m})$ with mean chromosome length varying between $1.12 \mu \mathrm{m}$ in $T$. weddelliana and $2.55 \mu \mathrm{m}$ in T. candida. Species based on $\mathrm{x}=7$ generally have shorter chromosomes than species with $\mathrm{x}=5$ and $\mathrm{x}=13$.

The presence of one pair of SAT-chromosomes is quite common in the genus, although in some species 2 pairs were detected. Macrosatellites and microsatellites have been reported usually attached to the short arm of m or sm chromosomes. T. hassleriana is the only species with a macrosatellite located on the long arm. No satellites were observed in T. weddelliana and T. melochioides, probably due to the small size of their chromosomes (Solís Neffa and Fernández, 1993; Solís Neffa, 1996).

Most of the Turnera species studied have karyotypes with a low degree of asymmetry due to the predominance of m-type chromosomes (Table III), and neither highly symmetrical karyotypes, those with all $\mathrm{m}$ chromosomes, nor bimodal karyotypes has been observed. The asymmetry in-

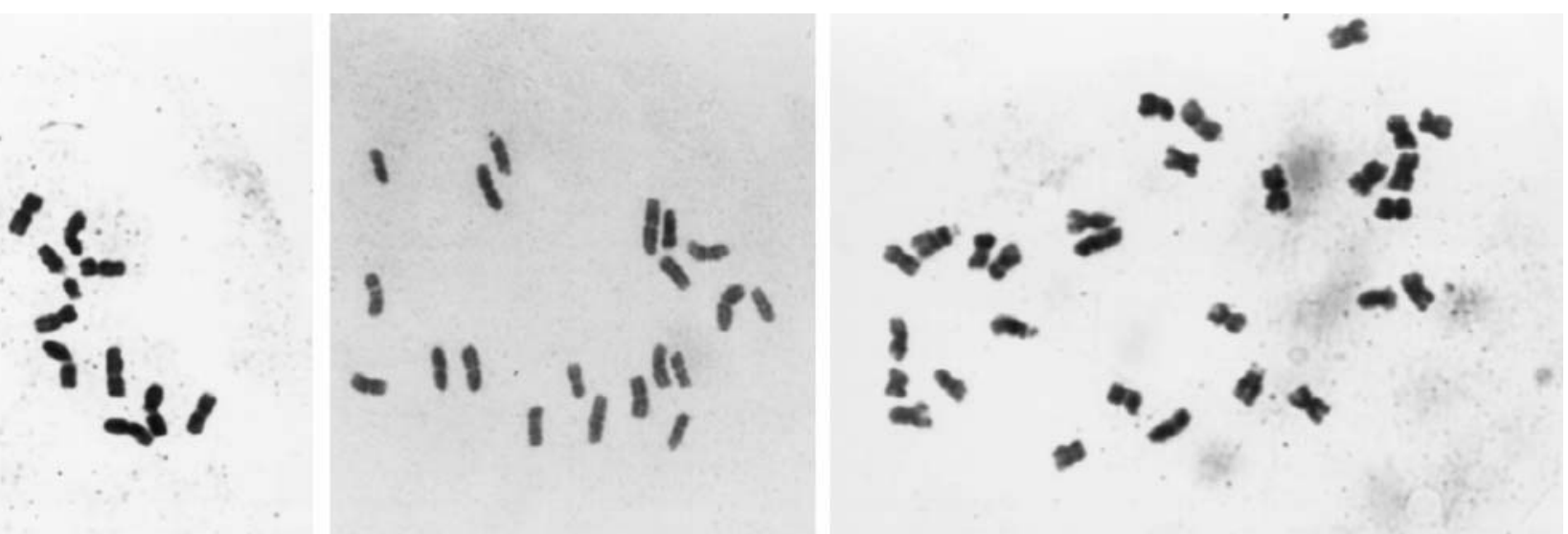

A

B

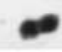

C
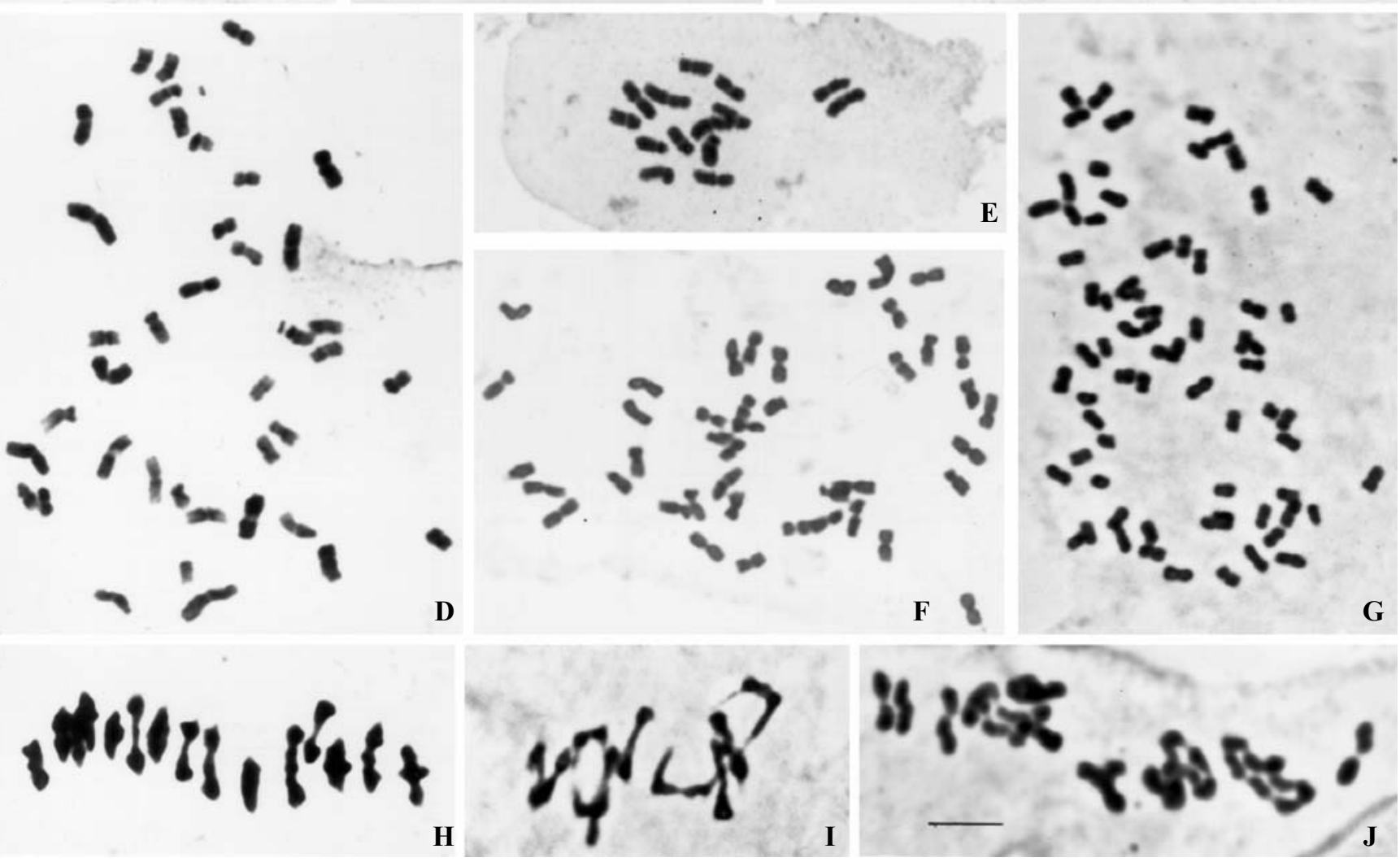

Figure 1 - Somatic and meiotic chromosomes of Turnera. A: T. grandiflora, $2 \mathrm{n}=2 \mathrm{x}=10 . \mathbf{B}:$ T. grandidentata, $2 \mathrm{n}=4 \mathrm{x}=20 . \mathbf{C}:$ T. ulmifolia, $2 \mathrm{n}=6 \mathrm{x}=30 . \mathbf{D}:$ T. aurelii, $2 \mathrm{n}=8 \mathrm{x}=40$. E: T. sidoides ssp. pinnatifida, $2 \mathrm{n}=2 \mathrm{x}=14$. F: T. sidoides ssp. integrifolia, $2 \mathrm{n}=6 \mathrm{x}=42$. G: T. opifera, $2 \mathrm{n}=10 \mathrm{x}=70$. $\mathbf{H}:$ T. ulmifolia, 15 II. I: T. scabra, 5 IV. J: T. grandiflora, 3 VIII + 2 IV + 4II. Scale $=5 \mu \mathrm{m}$. 
Table III - Karotype parameters. Chromosome numbers, ploidy level (X), karyotype formulae, mean chromosome length in $\mu \mathrm{m}$ (ML), centromeric index $(\mathrm{CI})$, intrachromosomal asymmetry index $\left(\mathrm{A}_{1}\right)$ and interchromosomal asymmetry index $\left(\mathrm{A}_{2}\right)$.

\begin{tabular}{|c|c|c|c|c|c|c|c|c|}
\hline Species & $2 \mathrm{n}$ & $\mathrm{X}$ & Karyotype formulae & ML & $\mathrm{CI}$ & $\mathrm{A}_{1}$ & $\mathrm{~A}_{2}$ & References \\
\hline T. weddelliana & 14 & 2 & $12 \mathrm{~m}+2 \mathrm{sm}$ & 1.12 & 42.29 & 0.28 & 0.18 & Solís Neffa and Fernández (1993) \\
\hline T. pumilea & 14 & 2 & $10 m+4 s m$ & 1.24 & 42.82 & 0.26 & 0.21 & Solís Neffa and Fernández (1993) \\
\hline T. melochioides & 14 & 2 & $10 m+4 s m$ & 1.33 & 42.10 & 0.25 & 0.28 & Solís Neffa (1996) \\
\hline T. hassleriana & 14 & 2 & $12 m+2 s m$ & 1.83 & 43.94 & 0.22 & 0.25 & Solís Neffa and Fernández (1993) \\
\hline T. chamaedryfolia & 26 & 2 & $16 m+8 s m+2 s t$ & 1.45 & 40.82 & 0.32 & 0.20 & Solís Neffa and Fernández (1993) \\
\hline T. candida & 10 & 2 & $8 m+2 s m$ & 2.55 & 41.95 & 0.25 & 0.19 & Solís Neffa (1996) \\
\hline T. caerulea & 10 & 2 & $8 m+2 s m$ & 2.53 & 44.00 & 0.23 & 0.18 & Solís Neffa (1996) \\
\hline T. grandiflora & 10 & 2 & $8 m+2 s m$ & 2.98 & 42.82 & 0.23 & 0.17 & Solís Neffa (1996) \\
\hline T. grandiflora & 40 & 8 & $32 m+8 s m$ & 1.83 & 44.58 & 0.21 & 0.24 & Solís Neffa and Fernández (1993) \\
\hline T. subulata & 10 & 2 & $8 m+2 s m$ & 1.71 & 45.50 & 0.17 & 0.13 & Solís Neffa and Fernández (1993) \\
\hline T. subulata & 20 & 4 & $16 \mathrm{~m}+2 \mathrm{sm}$ & 1.74 & 45.63 & 0.17 & 0.22 & Solís Neffa and Fernández (1993) \\
\hline T. scabra & 10 & 2 & $8 m+2 s m$ & 2.53 & 44.57 & 0.19 & 0.10 & Solís Neffa (1996) \\
\hline T. krapovickasii & 10 & 2 & $8 m+2 s m$ & 2.28 & 43.75 & 0.22 & 0.14 & Solís Neffa and Fernández (1993) \\
\hline T. krapovickasii & 20 & 4 & $16 \mathrm{~m}+4 \mathrm{sm}$ & 2.02 & 44.99 & 0.19 & 0.13 & Solís Neffa and Fernández (1993) \\
\hline T. concinna & 10 & 2 & $8 m+2 s m$ & 2.52 & 44.25 & 0.21 & 0.16 & Solís Neffa and Fernández (1993) \\
\hline T. hermannioides & 10 & 2 & $8 m+2 s m$ & 2.25 & 43.99 & 0.21 & 0.12 & Solís Neffa (1996) \\
\hline T. joelii & 10 & 2 & $8 m+2 s m$ & 2.37 & 43.54 & 0.21 & 0.11 & Solís Neffa (1996) \\
\hline T. grandidentata & 20 & 4 & $18 \mathrm{~m}+2 \mathrm{sm}$ & 2.06 & 45.58 & 0.16 & 0.20 & Solís Neffa and Fernández (1993) \\
\hline T. angustifolia & 30 & 6 & $26 m+4 s m$ & 1.88 & 44.44 & 0.21 & 0.14 & Solís Neffa and Fernández (1993) \\
\hline T. orientalis & 30 & 6 & $26 m+4 s m$ & 2.51 & 44.33 & 0.15 & 0.13 & Solís Neffa and Fernández (1993) \\
\hline T. ulmifolia & 30 & 6 & $24 m+6 s m$ & 2.32 & 42.57 & 0.23 & 0.13 & Solís Neffa and Fernández (1993) \\
\hline T. velutina & 30 & 6 & $28 \mathrm{~m}+2 \mathrm{sm}$ & 2.38 & 44.98 & 0.18 & 0.14 & Solís Neffa and Fernández (1993) \\
\hline T. aurelii & 40 & 8 & $36 m+4 s m$ & 2.21 & 44.58 & 0.15 & 0.24 & Solís Neffa and Fernández (1993) \\
\hline T. cuneiformis & 40 & 8 & $36 \mathrm{~m}+4 \mathrm{sm}$ & 1.36 & 44.78 & 0.20 & 0.14 & Solís Neffa and Fernández (1993) \\
\hline
\end{tabular}

dices proposed by Romero Zarco (1986) are important in that they allow the discrimination of clear differences among species (Figure 2). Asymmetry analysis has shown that $T$. chamaedryfolia of the Papilliferae series $(\mathrm{x}=13)$ has the highest tendency towards asymmetry while Turnera series species $(\mathrm{x}=5)$ have the smallest degree of asymmetry. Species with $\mathrm{x}=7$ showed an intermediate level of asymmetry.

Regarding series with $\mathrm{x}=7$, karyotype information is available for Salicifoliae and Leiocarpae. In the other series, only chromosome numbers have been reported. For the Salicifoliae series the karyotype of $T$. weddelliana has been studied (Table III), while for the Leiocarpae series $20 \%$ of the species have been cytologically investigated. Although Leiocarpae series is the largest series of the genus, chromosome numbers have been verified for only 8 species, with $2 \mathrm{n}=2 \mathrm{x}=14$ being the most common number, the karyotypes of 4 of which have been analyzed (Table III) and are characterized by the presence of small chromosomes and a moderate degree of asymmetry.

Recently the karyotypes of the T. sidoides complex $(\mathrm{x}=7)$ have been studied (Solís Neffa, V.G. and Fernández, A., unpublished results), and although this species belongs to the Leiocarpae series, it presents some unusual features (Arbo, 1985). Karyotype analysis of $T$. sidoides agrees with exomorphological data, and this species shares the basic number and the degree of karyotype asymmetry with the other species of the series but it differs in chromosome size, with the mean chromosome length more in accordance with the values for species of Turnera series (Solís Neffa, V.G. and Fernández, A., unpublished results). Moreover, $T$. sidoides is the only species in the Leiocarpae series having one pair of st-type chromosomes in its karyotype.

Turnera chamaedryfolia $(\mathrm{x}=13)$ belongs to the monotypic Papilliferae series. Karyotype characteristics confirm the distinctiveness of this taxon from other Turnera species, not only in basic chromosome number but also in karyotype asymmetry. This may be due to the high number of sm chromosomes and the presence of one pair of st chromosome in its karyotype formula (Table III).

The Turnera series presents the most complex floral structure in the family and is made up of about 22 species that are divided into two groups by seminal characters (Arbo, 1986). One of the groups constitutes the $T$. ulmifolia complex while the other comprises some tropical species (Fernández and Arbo, 1989), with species of each group being genetically related to each other (Arbo and Fernández, 1987).

Turnera ulmifolia is a polymorphic complex and Urban (1883) recognized more than 10 varieties with yellowand blue-flowered forms, which can be either heterostylous or homostylous. Shore and Barrett (1985) made a phenetic study based on morphological differentiation of 6 taxa; the results indicate that the complex is composed of several differentiated assemblages reproductively isolated from one another chromosomally via polyploidy, as well as genetically, via crossing barriers. These observations support the separation of the complex into several species. Most of the 


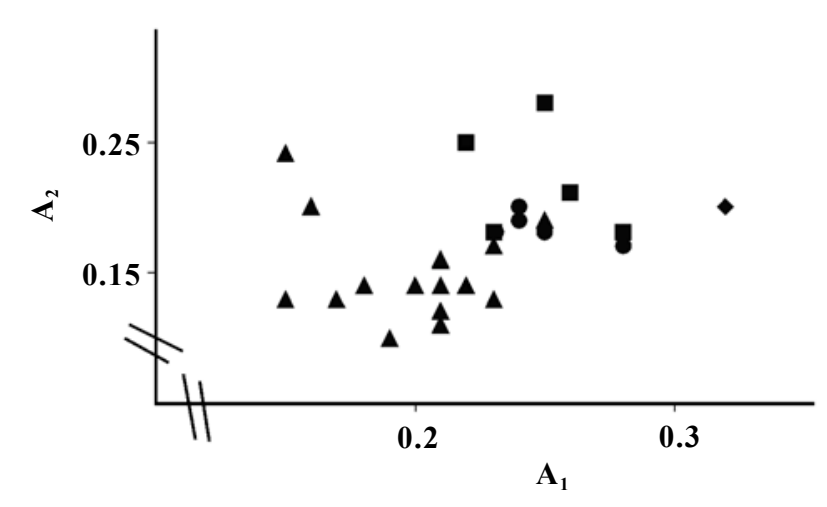

Figure 2 - Scatter diagram of mean intrachromosomal asymmetry index $\left(\mathrm{A}_{1}\right)$ against mean interchromosomal asymmetry index $\left(\mathrm{A}_{2}\right)$ for Turnera species. $\mathbf{\Lambda}: \mathrm{x}=5 . \mathbf{\square}: \mathrm{x}=7 . \diamond: \mathrm{x}=13 . \bullet$ : . sidoides complex.

varieties of T. ulmifolia are now recognized as independent species (Backer, 1951; Arbo, 1985). Cytological data (Fernández, 1987; Fernández and Arbo 1989, 1990, 1993a) and karyotype analysis (Solís Neffa and Fernández, 1993; Solís Neffa, 1996) support this separation.

No hybrids were obtained between yellow-flowered and blue-flowered diploid species (Arbo and Fernández, 1987). They are reproductively isolated because of their different genomes; all yellow-flowered species share the same basic genome A (Fernández and Arbo, 1989), while all blue-flowered have the basic genome $\mathrm{C}$ (Fernández and Arbo, 1996). These species share the karyotype formula $8 \mathrm{~m}+2 \mathrm{sm}$, which is considered the fundamental karyotype, nevertheless these taxa can differ by type and position of satellites, relative size of the chromosomes $\left(\mathrm{A}_{2}\right)$ and mean chromosome length.

\section{KARYOTYPE EVOLUTION IN THE GENUS TURNERA}

In Turnera there are different karyotypic evolutionary trends. Considering the published chromosome numbers and the data presented here, polyploidy is quite frequent in the genus. However, aneuploidy and dysploidy are also thought to be important in the chromosomic evolution of some species.

Data suggest that $x=7$ is the ancestral basic chromosome number of the genus, from which $x=5$ and $x=13$ could have been derived (Fernández, 1987), $\mathrm{x}=13$ being an unusual number within the genus since only one member of the genus has been identified as having this chromosome number. The origin of $x=13$ probably was by reductional aneuploidy from $2 n=4 x=28$.

Dysploid alteration of the basic chromosome number is usually the outcome of successive translocation, so that centromeres can be lost without damage to the plant. This brings about a reduction in chromosome number and a progressive increase in chromosome size, a mechanism which is supposed to be involved in the origin of $x=5$.
Dysploid changes may also explain the remarkable differences in chromosome size and karyotype asymmetry among species with $x=7$ and with $x=5$. Although in many Angiosperms symmetrical karyotypes are correlated with the primitive condition of the taxa (Stebbins, 1971), the major symmetry shown by species with $\mathrm{x}=5$ is in agreement with their derived basic number and would represent a secondary tendency in chromosome evolution.

Diploid species of the Turnera series show the same basic haploid karyotype, although some karyotype variation occurs among the species. They may be differentiated by type and position of satellites, the relative size of the chromosomes and mean chromosome length, differences which might be the result of structural chromosome rearrangements which occurred during the evolution of this species.

Polyploidy has been correlated with a decrease in chromosome length (Stebbins, 1938) and species with autopolyploid cytotypes show karyotypes with smaller chromosomes and more symmetry than in diploids (Solís Neffa and Fernández, 1993; Solís Neffa, 1996).

\section{CONCLUSION}

The data presented in this article suggest that there are different chromosomic evolutionary trends in Turnera. Cytological studies suggest that $x=7$ is the ancestral basic chromosome number for the genus, from which $x=5$ and $\mathrm{x}=13$ may have been derived. Although polyploidy has played an important role in speciation within the genus, aneuploidy and dysploidy have also occurred. The origin of $x=13$ probably was by reductional aneuploidy, while dysploid alteration is thought to be involved in the origin of $x=5$. Dysploid changes may also explain the differences in chromosome size and karyotype asymmetry among species.

Karyological data are meaningful in a systematic sense, since karyotype characteristics support taxonomic 
treatment of the species which can be distinguished by their mean chromosome length, type and position of satellites and karyotype asymmetry.

\section{ACKNOWLEDGMENTS}

This work was carried out with the economic support of CONICET and the Secretaría General de Ciencia y Técnica (UNNE).

\section{REFERENCES}

Arbo, M.M. (1985). Notas taxonómicas sobre Turneráceas sudamericanas. Candollea 40: 175-191.

Arbo, M.M. (1986). Paraguay, centro importante de especiación en las Turneráceas. En Spichiger \& Bocquet, ed., Notula ad Floram paraquaiensem 6. Candollea 41: 211-218.

Arbo, M.M. and Fernández, A. (1983). Posición taxonómica, citología y palinología de tres niveles de ploidía de Turnera subulata Smith. Bonplandia 5: 212-226.

Arbo, M.M. and Fernández, A. (1987). Cruzamientos intra e interespecíficos en Turnera, Serie Canaligerae. Bonplandia 6: 23-38.

Backer, C.A. (1951). Turneraceae. Flora Malesiana Ser. I 4: 235-238.

Barrett, S.C.H. (1978). Heterostyly in a tropical weed: the reproductive biology of the Turnera ulmifolia complex (Turneraceae). Can. J. Bot. 56: 1713-1725.

Barrett, S.C.H. and Shore, J. (1980). Variation in breeding systems in the Turnera ulmifolia complex. Second International Congress of Systematic and Evolutionary Biology, Vancouver, Canada (Abstracts, p. 10).

De Wet, J.M.J. (1980). Origins of polyploids. In: Polyploidy, Biological Relevance (Lewis, W.H., ed.). Plenum Press, New York, pp. 3-15.

Fernández, A. (1987). Estudios cromosómicos en Turnera y Piriqueta (Turneraceae). Bonplandia 6: 1-21.

Fernández, A. (1997). Estudio citogenético en híbridos entre una especie octoploide, Turnera aurelii y dos diploides, T. caerulea y T. joelii.
Bonplandia 9: 281-286.

Fernández, A. and Arbo, M.M. (1989). Relaciones genómicas entre cuatro especies diploides de Turnera con flores amarillas (Serie Canaligerae). Bonplandia 6: 93-109.

Fernández, A. and Arbo, M.M. (1990). Gametas no reducidas y relaciones genómicas en tres especies de Turnera (Turneraceae). Darwiniana 30: 21-26.

Fernández, A. and Arbo, M.M. (1993a). Relaciones genómicas entre seis especies de Turnera (Serie Canaligerae) del Paraguay. Candollea 48: 305-318.

Fernández, A. and Arbo, M.M.(1993b). Citogenética de híbridos entre Turnera grandidentata $(4 \mathrm{x})$ y $T$. subulata y T. scabra $(2 \mathrm{x})$ (Turneraceae). Bonplandia 7: 119-127.

Fernández, A. and Arbo, M.M. (1996). Relaciones genómicas entre las especies diploides de flores blanco-azuladas de Turnera (Serie Canaligerae). Bonplandia 9: 95-102.

Greilhuber, J. and Ehrendorfer, F. (1988). Karyological approaches to plant taxonomy. ISI Atlas Sci.: Anim. Plant Sci. 1: 289-297.

Hamel, J.L. (1965). Le noyau et les chromosomes somatiques de Turnera ulmifolia L. Mém. Mus. Natl. Hist. Nat. Sér. B 16: 3-8.

Raman, V.S. and Kesavan, P.C. (1964). Meiosis and nature of polyploidy in Turnera ulmifolia. J. Indian Bot. Soc. 43: 495-497.

Romero Zarco, C. (1986). A new method for estimating karyotype asymmetry. Taxon 35: 526-530.

Shore, J. and Barrett, S.C.H. (1985). The genetics of distyly and homostyly in T. ulmifolia L. (Turneraceae). Heredity 55: 167-174.

Solís Neffa, V.G. (1996). Cariotipos de especies de Turnera (Turneraceae). Bonplandia 9: 121-127.

Solís Neffa, V.G. and Fernández, A. (1993). Estudios cromosómicos en especies de Turnera (Turneraceae). Bonplandia 7: 101-118.

Soltis, D.E. and Riesberg, L.H. (1986). Autopolyploidy in Tolmeia menziesii (Saxifragaceae): genetic insights from enzyme electrophoresis. Am. J. Bot. 73:310-318.

Stebbins, G.L. (1938). Cytological characteristics associated with the different growth habits in the dicotyledons. Am. J. Bot. 25: 189-198.

Stebbins, G.L. (1971). Chromosomal Evolution in Higher Plants. AdissonWesley Publishing Company, Massachusetts.

Urban, I. (1883). Monographie der familie der Turneraceen. Jahrb. Königl. Bot. Gart. Berlin 2: 1-152. 